\title{
Fossil spiders (Araneae) from the Eocene Kishenehn Formation of Montana, USA
}

\author{
Matthew R. Downen and Paul A. Selden
}

\begin{abstract}
ABTRACT
The Kishenehn Formation contains a diverse assemblage of terrestrial arthropod fossils and represents a tropical ecosystem in North America during the Eocene (46 Ma). Most of the fossils are small insects, but spiders have also been recovered and recently made available for study. The fossil spiders are small and preserved as compressions in a thinly laminated oil shale, but abundant setae and other morphological features are preserved in relatively high detail. Here, the fossil spiders are described for the first time and include new species of orbweaving spiders from the family Araneidae and a ground-dwelling spider from the family Gnaphosidae. Most of the spiders in the assemblage resemble extant orbweaving spiders like Neoscona: Greenwaltarachne pamelae gen. \& sp. nov. and Consteniusi leonae gen. et sp. nov.. A single gnaphosid, distinguished by widely separated cylindrical spinnerets, is likely a juvenile. A single male spider belonging to Araneomorphae is too poorly preserved to discern at family level. The fossils described here are the oldest fossil spiders recovered from Montana thus far.
\end{abstract}

Matthew R. Downen. Department of Geology, University of Kansas, Ritchie Hall Earth, Energy \& Environment Center 1414 Naismith Drive, Room 254 Lawrence, KS 66045, USA.

matthew.downen@gmail.com

Paul A. Selden. Department of Geology, University of Kansas, Ritchie Hall Earth, Energy \& Environment Center 1414 Naismith Drive, Room 254 Lawrence, KS 66045, USA and Natural History Museum, Cromwell Road, London SW7 5BD, UK. selden@ku.edu

Keywords: Fossil-Lagerstätte; lacustrine; new genus; new species; taxonomy

Submission: 24 October 2020. Acceptance: 18 November 2020.

http://zoobank.org/5A215F0E-AE94-4250-9D22-E38DE45250E7

Downen, Matthew R. and Selden, Paul A. 2020. Fossil spiders (Araneae) from the Eocene Kishenehn Formation of Montana, USA. Palaeontologia Electronica, 23(3):a56. https://doi.org/10.26879/1135 palaeo-electronica.org/content/2020/3237-kishenehn-fossil-spiders

Copyright: December 2020 Paleontological Society.

This is an open access article distributed under the terms of Attribution-NonCommercial-ShareAlike 4.0 International (CC BY-NC-SA 4.0), which permits users to copy and redistribute the material in any medium or format, provided it is not used for commercial purposes and the original author and source are credited, with indications if any changes are made.

creativecommons.org/licenses/by-nc-sa/4.0/ 


\section{INTRODUCTION}

The Kishenehn Formation of Montana (Eocene: $46 \mathrm{Ma}$ ) is one of several Cenozoic lacustrine deposits of North America that are considered Fossil-Lagerstätten. A diverse assemblage of fossils is represented and includes terrestrial arthropods, plants, aquatic molluscs, and mammals (Pierce and Constenius, 2014). Small insects including flies (Diptera), true bugs (Hemiptera), and extremely minute fairy wasps (Hymenoptera: Mymaridae) are the most abundant fossils, while vertebrates are rare (Greenwalt and Labandeira, 2013; Greenwalt and Engel, 2014; Greenwalt et al., 2014; Lapolla and Greenwalt, 2015). The exceptional preservation has yielded even a bloodengorged mosquito with preserved biomolecules derived from hemoglobin (Greenwalt et al., 2013). Relatively few fossil spiders have been recovered this deposit and, hitherto, none have been described formally. This paper is a taxonomic survey of the fossil spider assemblage from the Kishenehn Formation.

The assemblage consists of new species of orbweaving spiders (Araneidae), a ground dwelling spider from the family Gnaphosidae, and an indeterminate araneomorph. Most of the spiders in the assemblage are conspecific and similar to extant spiders in the araneid spider genus Neoscona Simon, 1864. A single very small spider is likely a juvenile gnaphosid, based on cylindrical spinnerets. A single male spider is too poorly preserved to discern at family level and is left as an indeterminate araneomorph. Whereas none of the spiders described here extend the age range of any families, they do contribute to comparing spider assemblages preserved in Eocene lacustrine deposits across North America during the Eocene.

The fossil record of Araneidae extends back to the Cretaceous with the earliest araneid, Mesozygiella dunlopi Ortuño, 2006, preserved in amber from Álava, Spain (Penney and Ortuño, 2006). Araneids are one of the most diverse groups of spiders today (3100 species; World Spider Catalog, 2020), with many fossils described from amber (91 species). The Cenozoic record of Araneidae in North America currently includes araneids from the Dominican and Chiapas ambers and one lacustrine deposit, the Florissant Formation of Colorado (Scudder, 1890; Petrunkevitch, 1922, 1971; Wunderlich, 1982, 1986, 1988). The Florissant Formation (Eocene: $34 \mathrm{Ma}$ ) is a well-known lacustrine deposit with many exceptionally preserved insects and spiders, currently including 14 species of araneids in two genera: Araneus Clerck, 1757, and Tethneus Scudder, 1885, although many of these fossil spiders from the Florissant Formation are in need of revision (World Spider Catalog, 2020).

Gnaphosids are ground-dwelling spiders that do not weave webs to capture prey; instead, they actively hunt on the ground (Jocqué and Dippenaar-Schoeman, 2007). Gnaphosids and their relatives are distinguished from the aerial webspinning spiders by possessing only two tarsal claws, instead of three, and differing leg lengths. Gnaphosids themselves are distinguished easily from other similar spiders by their widely separated cylindrical spinnerets and claw tufts at the end of each leg (Platnick, 1990). There are currently 2522 species within Gnaphosidae, which also makes them one of the most diverse spider families. The fossil record of Gnaphosidae comes mostly from Baltic amber with 13 species (Menge, 1854; Wunderlich, 2011). Five species are from the Florissant Formation (34 Ma), but many of these need revision (Petrunkevitch, 1922).

\section{GEOLOGICAL SETTING AND FOSSIL PRESERVATION}

The Kishenehn Formation is located in northwestern Montana and is composed of two members: the Coal Creek Member and the overlying Pinchot Conglomerate Member. The Coal Creek Member is represented by an $1150 \mathrm{~m}$ thick succession of sandstone, siltstone, and oil shale (Constenius et al., 1989). Fossil insects and spiders are found in the middle of the Coal Creek Member in the oil shale. The fossils are preserved as compressions in extremely thin and delicate laminations representing varves. A thin layer of surface silicates obscures many of the fossils (Greenwalt et al., 2014).

The depositional setting and paleoenvironment is interpreted as a freshwater lacustrine system in a subtropical to tropical environment. Fishes, including bowfins (Amiidae) and suckers (Catostomidae), are indicative of freshwater habitats (Wilson, 1988). Sycamores are the most abundant plant fossils and represent humid and warm conditions, whereas other plants like cattails and waterferns are suggestive of paludal environments (Constenius et al., 1989). Relatively few mammal fossils have been recovered but include flying lemurs, which also support a tropical paleoenvironment (McKenna, 1990). 


\section{MATERIALS AND METHODS}

\section{Materials}

The specimens consist of a part only and are preserved in oil shale from the Coal Creek Member of the Kishenehn Shale in northwestern Montana. Greenwalt et al. (2013) lists specific sites of collection. Specimens (PAL 583.1, PAL 20412.1, PAL 32280, PAL 20480) are deposited in the Department of Paleobiology, National Museum of Natural History, Washington, D.C., with specimen labels beginning with PAL, and one specimen (CM 56099 ) is deposited in the Carnegie Museum of Natural History, Pittsburg, PA.

\section{Methods}

Due to the coating of silicates on the surface of the fossils, specimens were submerged in 95\% ethanol. The specimens were studied using a Leica M205C stereomicroscope, photographed with a Canon EOS 5D Mkll digital camera attached to the microscope and captured with DSLR Assistant software (www.kaasoft.com) on an Apple MacBook Pro computer. Drawings were made using a drawing tube attached to the microscope. Photographs were manipulated using Adobe Photoshop software. Fossils were also imaged using an Olympus BX51 Petrographic Scope with a mercury vapor-arc-discharge lamp, and two exciter filters designed to transmit in the UV (330-385 nm wavelength) and violet-blue (400-440 $\mathrm{nm}$ wavelength) region. This causes the matrix surrounding the fos-

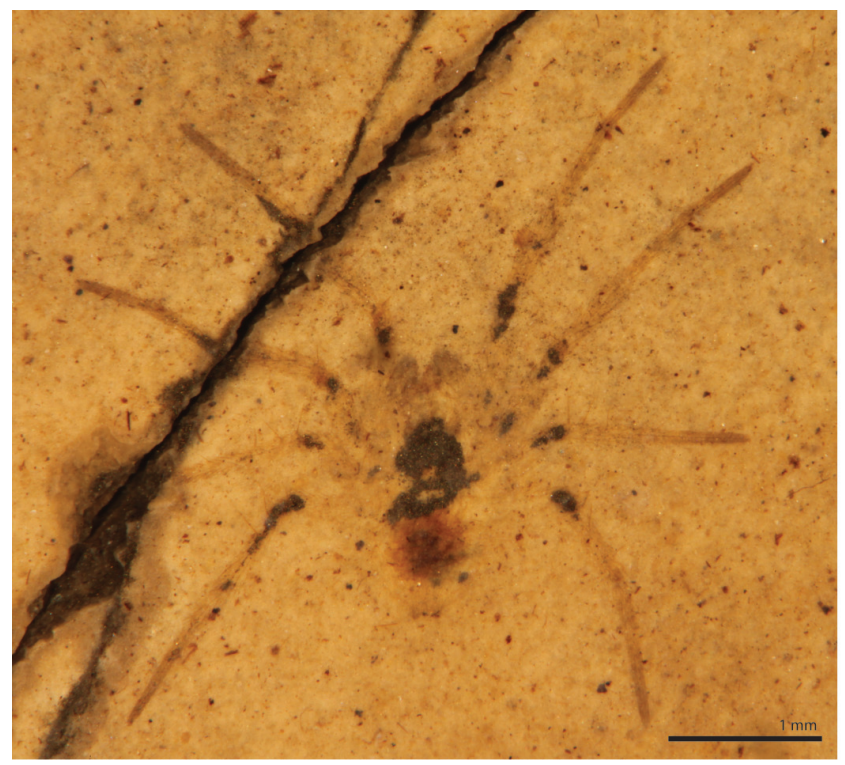

sils to fluoresce, and thus, increasing the contrast between matrix and cuticle/fossil material.

Abbreviations: AME anterior median eye(s), car carapace, ch chelicera, cx coxa, fe femur, $L$ length, Ib labium, LE lateral eye(s), mt metatarsus, mx maxilla, op opisthosoma, pa patella, Pd pedipalp, PME posterior median eye(s), sp spinnerets, st sternum, ta tarsus, ti tibia, $\mathrm{W}$ width.

\section{SYSTEMATIC PALEONTOLOGY}

Order ARANEAE Clerck, 1757

Suborder OPISTHOTHELAE Pocock, 1892

Infraorder ARANEOMORPHAE Smith, 1902

Araneomorphae incertae sedis

(Figure 1)

Remarks. Parts of this fossil spider are preserved with high fidelity (the legs), whereas other portions are poor in detail (the palps and carapace). The palps, carapace, and some of the leg joints have been replaced with pyrite which contributes to a loss of detail. Mygalomorph spiders typically have large porrect chelicerae and robust legs. The fossil here has relatively small chelicerae that are not porrect, and legs that are relatively slender with heavy spination. The pedipalps are modified, indicating the specimen is an adult male. A large cymbium is observable on each palp, as well as a median apophysis and other structures of the palpal bulb, suggesting it is relatively complex like most araneomorph spiders. Most of the femora are distorted (likely due to compression) and are likely longer than they appear. The third leg of the spider

FIGURE 1. Specimen PAL 583.1 Araneomorphae incertae sedis photograph and interpretive drawing. 
is the shortest, but it is not quite as short as most orbweaving spiders. Tarsus IV possesses fine setae, but no tarsal comb is visible, as is in the family Theridiidae. Two tarsal claws can be made out on some legs, and there do not appear to be any dense claw tufts or scopulae, so the specimen is unlikely to belong to Clubionidae or Corinnidae.

Description of PAL 583.1. Male Carapace rounded, longer than wide ( $\mathrm{L} 0.62, \mathrm{~W} 0.48$ ). Abdomen about as long as wide ( $\mathrm{L} 0.76, \mathrm{~W} 0.78$ ), with circular darkened area at anterior extending to almost full length of abdomen. Spinnerets small and conical, at posterior most tip of abdomen (abdomen does not overhang spinnerets). Cymbium oval, almost half the length of the carapace, covered in fine setae. Hook-shaped median apophysis. Walking leg formula $|>||>| V>|I|$. Legs spinose and covered in fine setae and erect long and thick spine-like macrosetae. Single spine-like macrosetae on each patella, two on proximal tibia of all legs. Shorter macrosetae on metatarsus.

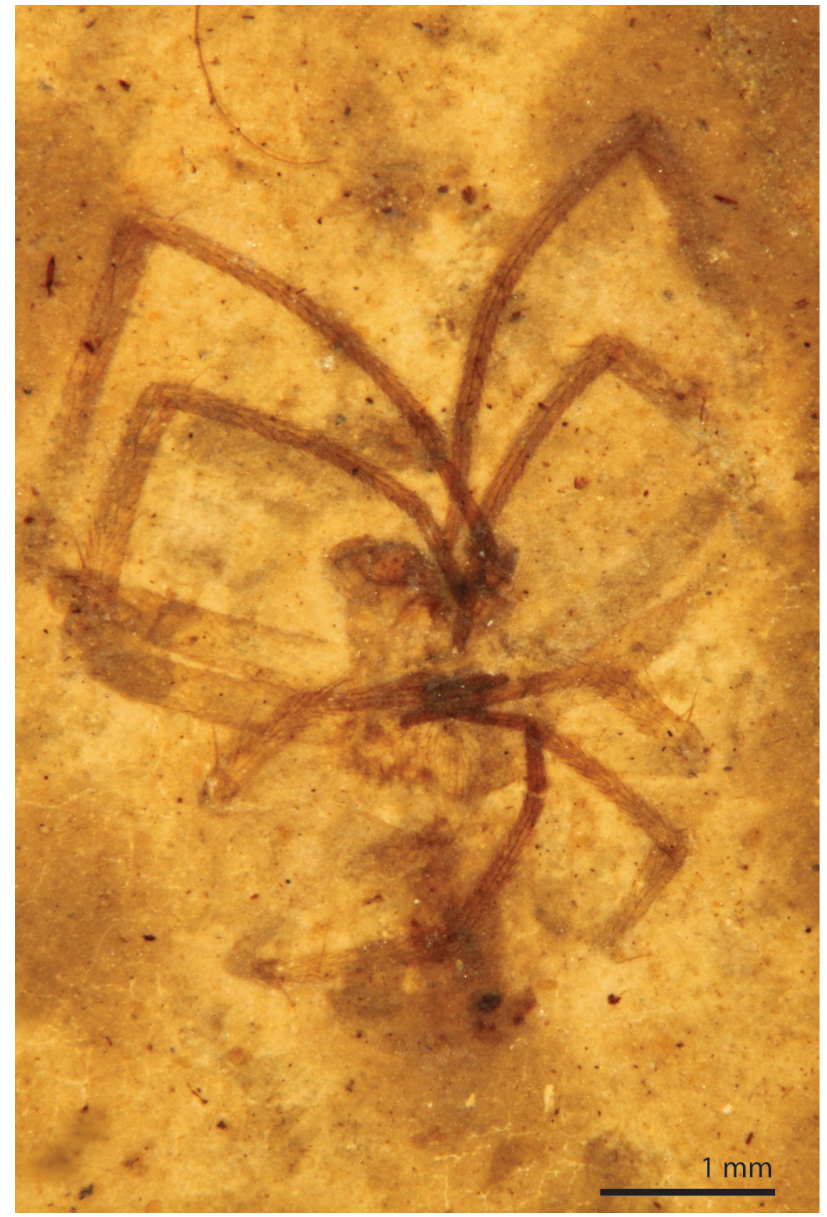

\section{Superfamily ARANEOIDEA \\ Family ARANEIDAE Clerck, 1757}

Remarks. The following fossils are placed in the family Araneidae based on the following characteristics: three clawed, entelegyne, ecribellate, long slender legs, and a shortest third pair of legs. The spiders lack a tarsal comb on the fourth tarsus and possesses spine-like macrosetae on some ti and $\mathrm{mt}$, excluding them from Theridiidae. The spiders also lack a calamistrum and femoral trichobothria excluding them from Uloboridae. The spiders are excluded from Linyphiidae by lacking a single $\mathrm{mt}$ trichobothrium on Legs I-IV (although this just may not be visible), and by possessing sternum that does not extend beyond coxa IV and tarsi that are tapering rather than cylindrical.

\section{Araneidae incertae sedis}

(Figure 2)

Description of PAL 20412.1. Male. Carapace longer than wide ( $L$ 1.3, W 0.91). Posterior half of sternum pointed, with sparse fine setae. Abdomen

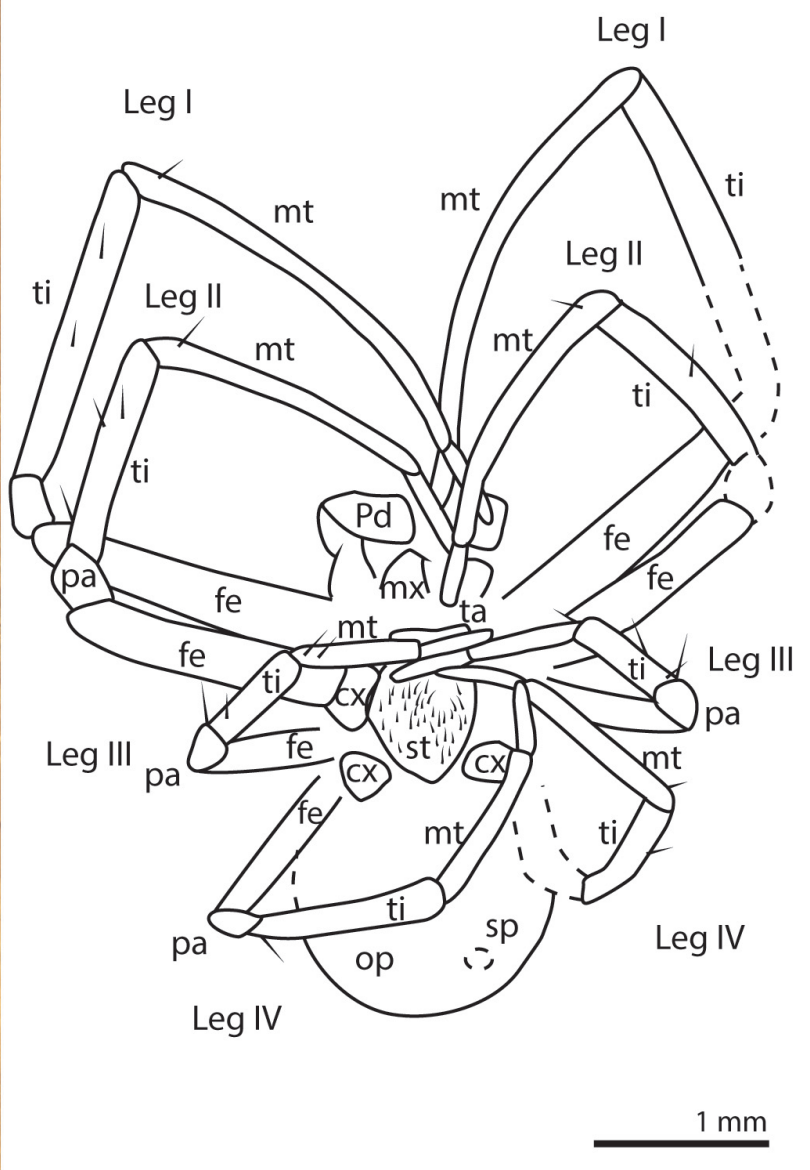

FIGURE 2. Specimen PAL 20412.1 Araneidae incertae sedis photograph and interpretive drawing. 
rounded, about as long as wide ( $\mathrm{L} 1.2, \mathrm{~W}$ 1.37); dark patch running through the abdomen midline. Walking leg formula $|>||>| V>|| \mid$.; legs long and slender, clothed in dense fine setae; Leg III distinctly short (2.5x shorter than Leg 1); Metatarsi of Legs I and II noticeably curved; relatively few erect spinelike macrosetae on all legs: one on proximal $\mathrm{mt}$ of Legs I, II, III, none on Leg IV mt; two on proximal ti of Leg III; one proximal and one distal on Leg IV ti. Podomere lengths: Leg I fe 1.57, pa 0.24, ti 1.59, mt 1.91, ta 0.56, Leg II fe 1.31, pa 0.28, ti 1.10 , mt 1.36, ta 0.49 , Leg III fe 0.68 , pa 0.18 , ti 0.55 , mt 0.59 , ta 0.44 , Leg IV fe 1.04 , pa 0.15 , ti 0.75 , mt 0.93 , ta 0.36 .

Remarks. The position of the legs of this spider is similar to fossil uloborids from Montsech, Spain (Cretaceous) and the Daohugou Beds of China (Jurassic), however no plumose or feathery setae, which are present in uloborids, were observed. The seta of this spider appears smooth. The spider also lacks a cribellum and calamistrum, but these features are lost in adult male uloborids.

\section{Genus Consteniusi gen. nov.}

\section{zoobank.org/C1ED0776-DD21-4137-A576-6425C68CD276}

Diagnosis. Distinguished from all other araneids by the combination of a subtriangular abdomen and a cluster of four long thin setae on the palpal patella.

Etymology. The fossil genus is named for Kurt Constenius who collected the fossil.

Type species. Consteniusi leonae n. sp. (monotypic).

\section{Consteniusi leonae sp. nov.}

(Figure 3)

\section{zoobank.org/6587C4F5-0665-4DE7-B6A9-72B72DCFFA09}

Etymology. The fossil, nicknamed Leona's Spider, is named for the mother of Kurt Constenius, Leona, who graciously donated the specimen for study.

Type. Holotype adult female, only known specimen, part only, specimen CM 56099 from Coal Creek Member of the Kishenehn Formation; Eocene age; northwestern Montana; deposited in the Carnegie Museum of Natural History, Pittsburg, PA.

Diagnosis. As for the genus.

Description of CM 56099. Sternum triangular, longer than wide, with setae that lengthen anteriorly. Labium triangular, wider than long. Maxillae short and stout, widest anteriorly. Chelicerae robust and stout. Palps with abundant setae and macrosetae. Abdomen subtriangular, wider than long ( $L$ 0.0.87, W 0.95), distinctly sclerotized portion round and half the length of abdomen. Colulus present. Walk- ing leg formula $|>||>| V>|I|$. Legs covered in abundant spine-like macrosetae. Single trichbothrium on proximal tibia of legs III and IV just after pa-ti joint. Length of $\mathrm{mt}+\mathrm{ta}>\mathrm{ti}+\mathrm{pa}$.

Podomere lengths: $\mathrm{Pd} 0.42$ (visible); leg I fe 1.01,

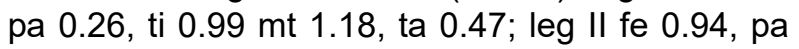
0.21 , ti 0.71 , mt 0.83 , ta 0.0 .36 ; leg III fe 0.56 , pa 0.16 , ti 0.41 , mt 0.4 , ta 0.25 ; leg IV fe 0.82 , pa 0.2 , ti 0.52 , mt 0.62 , ta 0.24 .

Remarks. The fossil is similar to Metepeira in that the combined length of metatarsus $I$ and tarsus $I$ is greater than the combined length of tibia $I$ and patella I (Piel, 1998). The subtriangular abdomen is similar to Neoscona in ventral view, although the abdomen is slightly more rounded in Neoscona (Berman and Levi, 1971). The fossil also has a distinct patch of color on the anterior ventral portion of the abdomen. Many species in the subfamily Araneinae are distinguished by ventral patches of color, but any patterns useful for classification are not visible here.

\section{Genus Greenwaltarachne gen. nov.}

zoobank.org/F2817293-7BF1-4687-973B-47D289D56441

Diagnosis. Distinguished from all other araneids by the combination of characters: an abdomen widely overhanging spinnerets, annulated legs with two dark bands on metatarsus IV, the single trichobothrium at the distal most edge of the metatarsus just before the mt-ta joint.

Etymology. The fossil species is named for Dale Greenwalt of the Smithsonian Natural Museum of Natural History who pushed for the spiders to be studied and "arachne" for spider.

Type species. Greenwaltarachne pamelae n. sp. (monotypic).

\section{Greenwaltarachne pamelae sp. nov.}

(Figure 4)

\section{zoobank.org/4103050F-F23B-457A-BF45-075B41247CAA}

Etymology. The fossil species is named for the author's (MRD) mother Pamela.

Type. Holotype adult female, part only, from Coal Creek Member of the Kishenehn Formation; Eocene age; northwestern Montana; deposited in the Smithsonian Institution National Museum of Natural History, Paleobiology Department.

Diagnosis. As for the genus.

Description of PAL 32280. Carapace oval in outline, longer than wide ( $L$ 1.49, W 0.87); sternum heart shaped, longer than wide, attenuated posteriorly, not extending past coxae IV; Labium rebordered (thickened anteriorly), wider than long. Abdomen rounded, longer than wide $(\mathrm{L} 1.59, \mathrm{~W}$ $1.38)$, clothed in setae, projecting beyond spinner- 

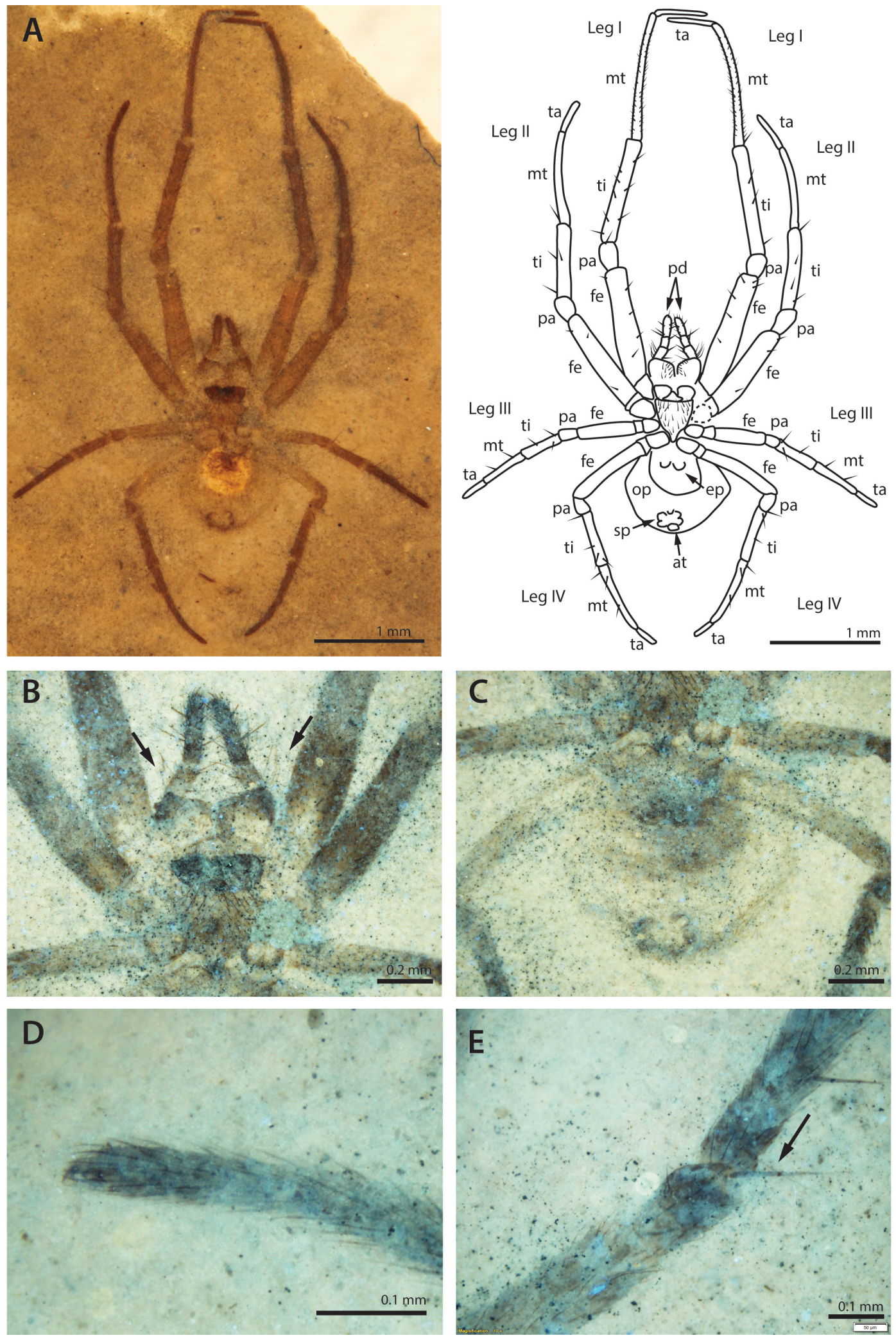

FIGURE 3. Specimen CM 56099 Consteniusi leonae gen. et sp. nov. A) photograph and interpretive drawing. B) Prosoma region and palps with cluster of long macrosetae (arrow) in UV light. C) Opisthosomal region in UV light showing subtriangular abdomen in UV light. D) Tarsus of Leg IV showing claws and setae in UV light. E) Leg III pa-ti joint with macrosetae and trichobothrium (arrow). 

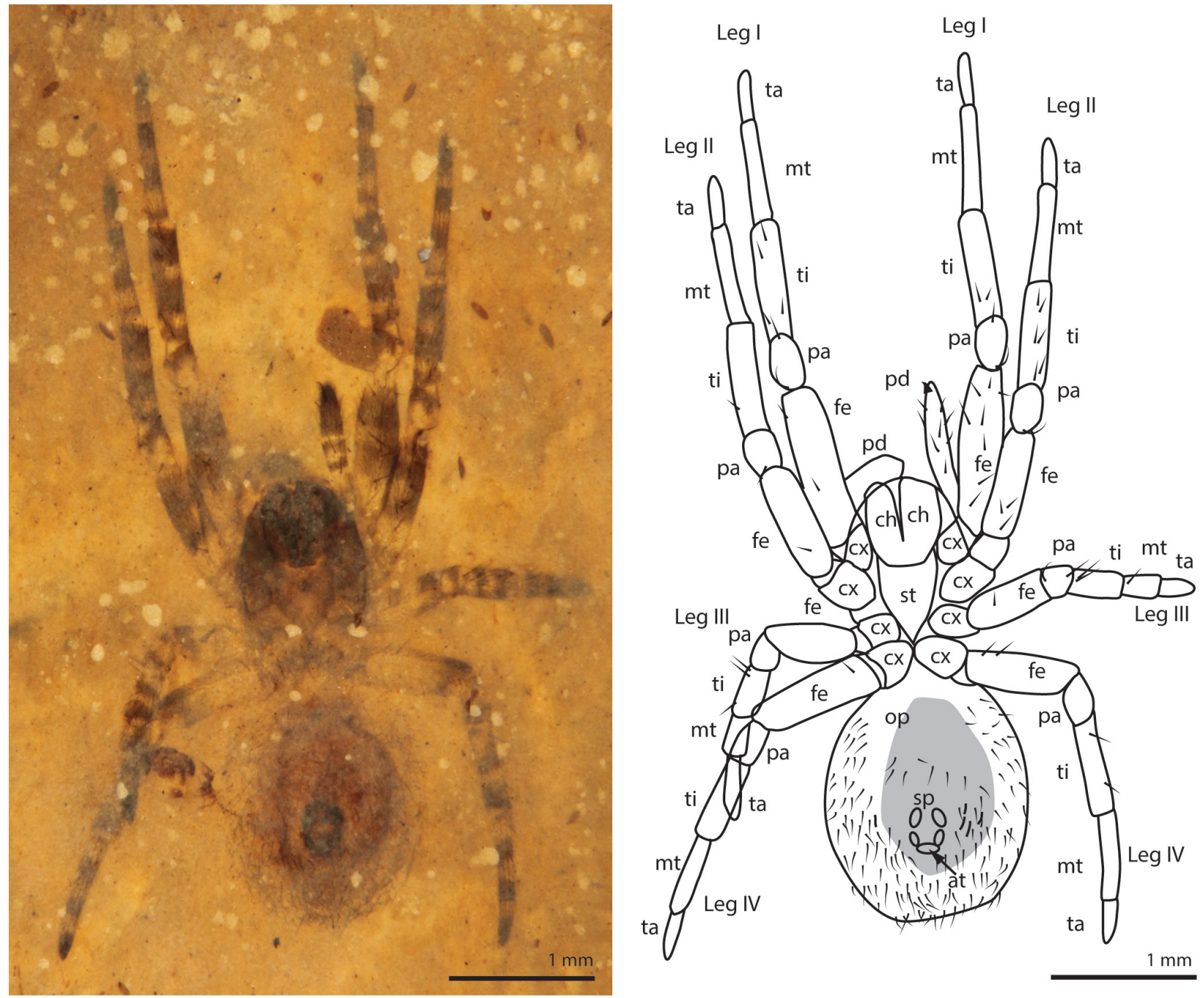

FIGURE 4. Specimen PAL 32280 Greenwaltarachne pamelae gen. et sp. nov. photograph and interpretive drawing.

ets. Walking leg formula |>||>|V>|II.; stout, but tapering legs, Leg III noticeably short; legs covered in dense fine setae, large macrosetae on most podomeres; trichobothrium on distal Leg IV mt; Legs striped with colored (darkened) bands; Leg IV fe with only distal darkening.

Podomere lengths: Pd 0.77 (visible); leg I fe 1.22, pa 0.34 , ti $0.85 \mathrm{mt} 0.74$, ta 0.38 ; leg II fe 0.9 , pa 0.31 , ti 0.8 , mt 0.59 , ta 0.33 ; leg III fe 0.49 , pa 0.2 , ti 0.34 , mt 0.35 , ta 0.24 ; leg IV fe 0.73 , pa 0.29 , ti $0.64, \mathrm{mt} 0.54$, ta 0.30 .

Remarks. The banded legs and podomere lengths resemble those of other araneid genera like Larinioides, Neoscona, and Zygiella (Baba and Tanikawa, 2015; Tanikawa, 2017; Framenau, 2019). Neoscona has fewer bands on Leg IV, and specifically, only one band on metatarsus IV. Some Larinioides have two bands on metatarsus IV, but the distal half of tibia IV is a solid band, in contrast to the fossil. Zygiella also has banded legs, although lighter in color and an abdomen that does not overhang the spinnerets as much as what is observed in the fossil.

\section{Clade DIONYCHA}

Family Gnaphosidae Pocock, 1898

Remarks. The fossil is placed in the family Gnaphosidae based on the stout legs (Walking leg formula 4123) and widely separated lateral spinnerets.

\section{Gnaphosidae incertae sedis}

(Figure 5).

Description of PAL 20480. Carapace outline suboval, longer than wide ( $L 0.77$, W 0.46). Chelicerae relatively large, projecting forward. Abdomen longer than wide ( $\mathrm{L} 1.24, \mathrm{~W}$ 0.73). Labium triangular, 

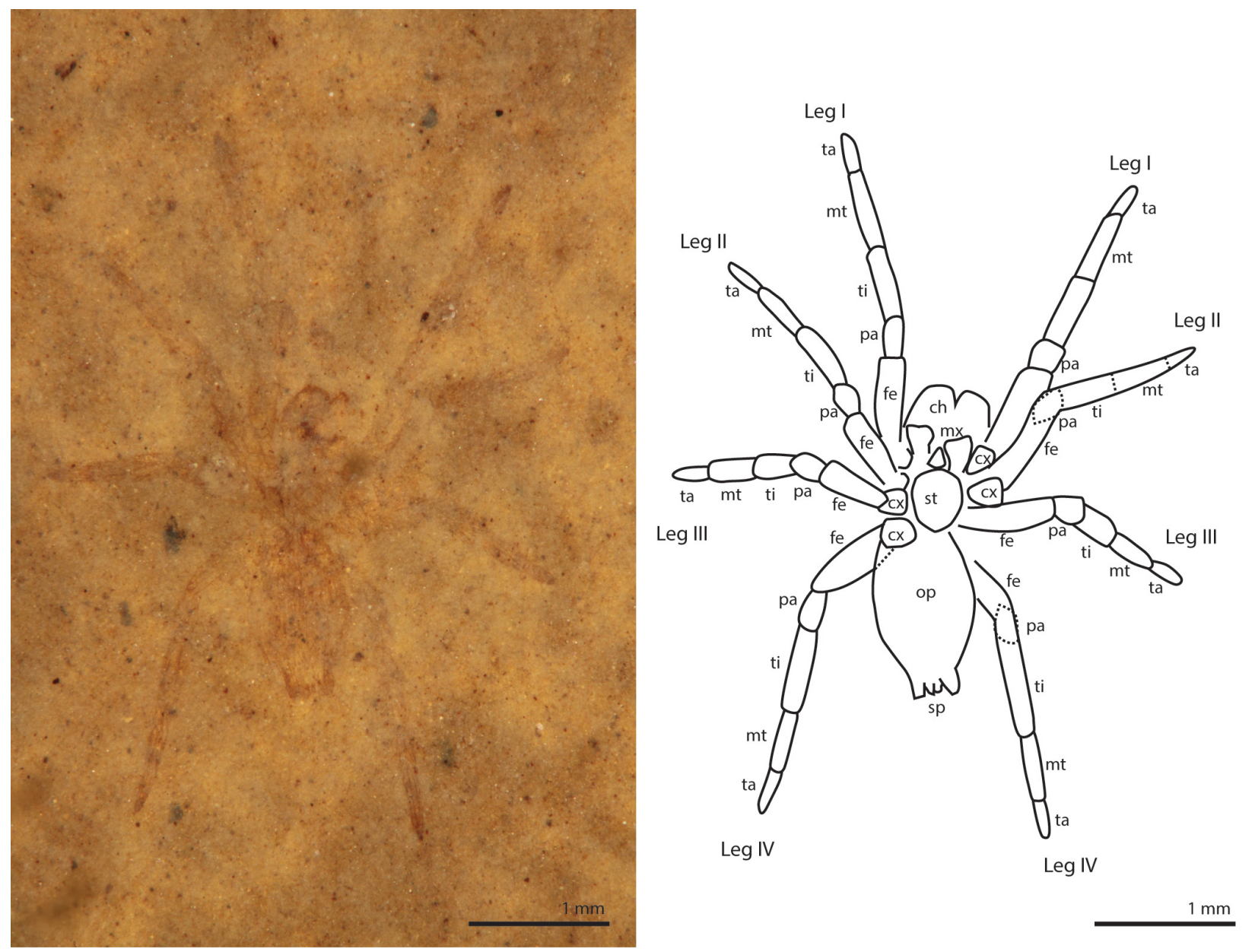

FIGURE 5. Specimen PAL 20480 Gnaphosidae incertae sedis photograph and interpretive drawing.

as long as wide, and notched distally. Maxillae slightly narrowed at center. Sternum ovoid. Body and legs clothed in dense short setae. Relatively few macrosetae on legs. Claw tufts present.

Podomere lengths: Leg I fe 0.60 , pa 0.27 , ti 0.56 , mt 0.57, ta 0.29; Leg II fe 0.59, pa 0.29, ti 0.46, mt 0.43 , ta 0.26 ; Leg III fe 1.21 pa 0.23 , ti 0.29 , mt 0.35 , ta 0.25 ; Leg IV fe 0.65 pa 0.30 , ti 0.67 , mt 0.48 , ta 0.30 .

Remarks. The small size of the specimen suggests it is a juvenile. There are also no clear reproductive structures visible and the palps are not inflated. The fossil also resembles spiders from Clubionidae and Corinnidae. Both corinnids and clubionids usually have well-developed spines on the legs. Corinnids have shorter spinnerets that are closer together. Clubionids can have elongated cylindrical spinnerets like gnaphosids, but the anterior lateral spinnerets are not as widely separated in clubionids.

\section{DISCUSSION}

Although relatively few fossil spiders have been recovered from the Kishenehn Formation thus far, they are still the first formally described spiders from the Eocene of Montana. Fossil spiders have been reported from the Oligocene Canyon Ferry Fossil-Lagerstätte of Montana, but remain undescribed (CoBabe et al., 2002). Other Eocene lacustrine deposits from which fossil spiders have been recovered include the Green River and Florissant formations of Colorado, and Horsefly, British Columbia, Canada.

The Kishenehn fossil assemblage consists mostly of aerial web weaving spiders, which are found in the other Cenozoic lacustrine deposits. The orbweaving spider Greenwaltarachne pamelae is easily recognizable from the striped pattern on its legs and four other spiders from this deposit appear to be the same species. Orbweaving spiders are also found in the Green River Formation (Selden and Wang, 2014), although not of the 
same family (Tetragnathidae), and none of the spiders appear to resemble G. pamelae. Another similarity between the Kishenehn and Green River spider assemblages is their relatively small size, which is likely the result of taphonomic bias. The only fossil spider formally described from Horsefly is a pisaurid (Pisauridae), ground-dwelling spiders often referred to as fishing spiders or more commonly known as nursery web spiders (Selden et al., 2009). No such spiders have been found in the Kishenehn Formation thus far, but pisaurids are present in the Florissant Formation. The Florissant Formation contains a much more diverse assemblage of spiders in a variety of families including Araneidae and Gnaphosidae (Scudder, 1890; Petrunkevitch, 1922). The gnaphosid described here does not extend the age range of Gnaphosi- dae, as several gnaphosids have been described from Baltic amber, but it is the oldest representative of the family found so far in North America.

\section{ACKNOWLEDGEMENTS}

We thank D. Greenwalt reaching out about the spiders for study, C. Labandeira and M. Florence (National Museum of Natural History, USA) for loan of the specimens in collections at the Smithsonian, and Kurt Constenius (University of Arizona, USA) and family for donation of the special spider; and A. Olcott (University of Kansas, USA) for use of the fluorescence microscope. We thank two anonymous reviewers for their valuable comments on the manuscript.

\section{REFERENCES}

Baba, Y. and Tanikawa, A. 2015. The handbook of spiders. Bun-Ichi Sogo Shuppan, Tokyo.

Berman, J.D. and Levi, H.W. 1971. The orb weaver genus Neoscona in North America (Araneae: Araneidae). El género de tejedoras de esferas del género Neoscona en Norteamérica (Araneae: Araneidae). Bulletin of the Museum of Comparative Zoology at Harvard College, 141:465-500.

Clerck, C. 1757. Aranei Svecici. Svenska spindlar, uti sina hufvud-slågter indelte samt under några och sextio särskildte arter beskrefne och med illuminerade figurer uplyste. Stockholmiae. https://doi.org/10.5962/bhl.title.119890

CoBabe, E.A., Chamberlain, K.R., Ivie, M.A., and Giersch, J.J. 2002. A new insect and plant Lagerstatte from a Tertiary lake deposit along the Canyon Ferry Reservoir, southwestern Montana. Rocky Mountain Geology, 37:13-30. https://doi.org/10.2113/gsrocky.37.1.13

Constenius, K.N., Dawson, M.R., Pierce, H.G., Walter, R.C., and Wilson, M.V.H. 1989. Reconnaissance paleontologic study of the Kishenehn Formation, northwestern Montana and southeastern British Columbia. Montana Geological Society 1989 Field Conference Guidebook. Montana Centennial Edition, Geologic Resources of Montana, 1:189-203.

Framenau, V.W. 2019. Generic and family transfers, and numina dubia for orb-weaving spiders (Araneae, Araneidae) in the Australasian, Oriental and Pacific regions. Evolutionary Systematics, 3:1-27. https://doi.org/10.3897/evolsyst.3.33454

Greenwalt, D. and Engel, M.S. 2014. A diminutive pelecinid wasp from the Eocene Kishenehn Formation of northwestern Montana (Hymenoptera: Pelecinidae). Novitates Paleoentomologicae, 8:1-9. https://doi.org/10.17161/np.v0i8.4750

Greenwalt, D. and Labandeira, C. 2013. The amazing fossil insects of the Eocene Kishenehn Formation in Northwestern Montana. Rocks \& Minerals, 88:434-441. https://doi.org/10.1080/00357529.2013.809972

Greenwalt, D.E., Goreva, Y.S., Siljeström, S.M., Rose, T., and Harbach, R.E. 2013. Hemoglobinderived porphyrins preserved in a Middle Eocene blood-engorged mosquito. Proceedings of the National Academy of Sciences of the United States of America, 110:18496-18500. https://doi.org/10.1073/pnas.1310885110

Greenwalt, D.E., Rose, T.R., Siljestrom, S.M., Goreva, Y.S., Constenius, K.N., and Wingerath, J.G. 2014. Taphonomy of the fossil insects of the middle Eocene Kishenehn Formation. Acta Palaeontologica Polonica, 60:931-948.

Jocqué, R. and Dippenaar-Schoeman, A.S. 2007. Spider Families of the World. Royal Museum for Central Africa, Tervuren. 
Lapolla, J.S. and Greenwalt, D.E.,2015. Fossil ants (Hymenoptera: Formicidae) of the Middle Eocene Kishenehn Formation. Sociobiology, 62:163-174. https://doi.org/10.13102/sociobiology.v62i2.163-174

McKenna, M.C. 1990. Plagiomenids (Mammalia:? Dermoptera) from the Oligocene of Oregon, Montana and South Dakota, and Middle Eocene of northwestern Wyoming: dawn of the age of mammals in the northern part of the Rocky Mountain Interior, North America. Geological Society of America, Special Paper, 243:211-234. https://doi.org/10.1130/spe243-p211

Menge, A. 1854. Footnotes in Koch, C.L. and Berendt, G.C. Die im Bernstein befindlichen Myriapoden, Arachniden und Apteren der Vorwelt. In Berendt, G.C. (ed.), Die in Bernstein befindlichen organischen Reste der Vorwelt gesammelt in Verbindung mit mehreren bearbeitetet und herausgegeben 1. Berlin, Nicolai.

Penney, D. and Ortuño, V.M. 2006. Oldest true orb-weaving spider (Araneae: Araneidae). Biology Letters, 2:447-450. https://doi.org/10.1098/rsbl.2006.0506

Petrunkevitch, A. 1922. Tertiary spiders and opilionids of North America. Transactions of the Connecticut Academy of Sciences, 25:211-279.

Petrunkevitch, A. 1971. Chiapas amber spiders. II. California University Publications in Entomology, 63:1-44.

Piel, W.H. 1998. The systematics of neotropical orb-weaving spiders in the genus Metepeira (Araneae, Araneidae). Unpublished PhD Thesis, Harvard University, Cambridge Massachusetts, USA.

Pierce, H.G. and Constenius, K.N. 2014. Terrestrial and aquatic mollusks of the Eocene Kishenehn Formation, Middle Fork Flathead River, Montana. Annals of the Carnegie Museum, 82:305-329. https://doi.org/10.2992/007.082.0401

Platnick, N.I. 1990. Spinneret morphology and the phylogeny of ground spiders (Araneae, Gnaphosoidea). American Museum Novitates, 2978:1-42.

Pocock, R.I. 1898. The Arachnida from the province of Natal, South Africa, contained in the collection of the British Museum. Annals and Magazine of Natural History Series 7, 2(9):197226. https://doi.org/10.1080/00222939808678036

Scudder, S.H. 1890. The Tertiary Insects of North America. U.S. Government Printing Office.

Selden, P.A. and Wang, Y. 2014. Fossil spiders (Araneae) from the Eocene Green River Formation of Colorado. Arthropoda Selecta, 23:207-219. https://doi.org/10.15298/arthsel.23.2.10

Selden, P.A., Penney, D., Kropf, C., and Horak, P. 2009. A fossil spider (Araneae: Pisauridae) of Eocene age from Horsefly, British Columbia, Canada. Contributions to Natural History, 12:1269-1282.

Simon, E. 1864. Histoire naturelle des araignées (aranéides). Paris.https://doi.org/10.5962/ bhl.title.47654

Smith, F.P. 1902. The spiders of Epping Forest. Essex Naturalist, 12:181-201.

Tanikawa, A. 2017. A new species of Zygiella from Amami-ôshima Island, Japan (Araneae: Araneidae). Acta Arachnologica, 66:1-4.

Wilson, M.V.H. 1988. Reconstruction of ancient lake environments using both autochthonous and allochthonous fossils. Palaeogeography, Palaeoclimatology, Palaeoecology, 62:609_ 623. https://doi.org/10.1016/0031-0182(88)90074-0

Wunderlich, J. 1982. Die häufigsten Spinnen (Araneae) des Dominikanischen Bernsteins. Neue Entomologische Nachrichten, 1:26-45.

Wunderlich, J. 1986. Spinnenfauna gestern und heute. Fossile Spinnen in Bernstein und ihre heute lebenden Verwandten. Wiesbaden. Bauer bei Quelle \& Meyer.

Wunderlich, J. 1988. Die Fossilen Spinnen im Dominikanischen Bernstein. Beiträge zur Araneologie, 2:1-378.

Wunderlich, J. 2011. Taxonomy of extant and fossil (Eocene) European ground spiders of the family Gnaphosidae (Araneae), with a key to the genera, and descriptions of new taxa. Beiträge zur Araneologie, 6:19-97. 